\title{
ON THE OSTROWSKI'S INTEGRAL INEQUALITY FOR MAPPINGS WITH BOUNDED VARIATION AND APPLICATIONS
}

\author{
S. S. DRAGOMIR
}

Abstract. A generalization of Ostrowski's inequality for mappings with bounded variation and applications in Numerical Analysis for Euler's Beta function is given.

Mathematics subject classification (2000): 26D15, 41A55.

Key words and phrases: Ostrowski's inequality, numerical integration, beta mapping.

\section{REFERENCES}

[1] S. S. Dragomir and S. Wang, A new inequality of Ostrowski's type in $L_{1}$ norm and applications to some special means and to some numerical quadrature rules, Tamkang J. of Math., 28(1997), 239-244.

[2] D. S. Mitrinović, J. E. PeČARIĆ, AND A. M. FinK, Inequalities for Functions and their Integrals and Derivatives, Kluwer Academic Publishers, 1994. 